\title{
OBASANJO'S ADMINISTRATION ANTI-CORRUPTION CAMPAIGN IN NIGERIA AND SALIENT GOVERNANCE IMPLICATIONS
}

\author{
${ }^{1}$ Salisu Ojonemi PAUL (Corresponding Author) \\ Public Administration and Local Government Studies, \\ University of Nigeria, Nsukka \\ salisunelson@gmail.com \\ ${ }^{2}$ Ali Yakubu \\ School of Business Administration, \\ Department of Office Technology Management, \\ Federal Polytechnic, Idah, Nigeria \\ talk2bogger2000@yahoo.com

\section{${ }^{3}$ Grace Iye Apeh} \\ School of General and Administrative Studies, \\ Department of Languages, \\ Federal Polytechnic, Idah, Nigeria \\ graceiyeapeh@gmail.com
}

\begin{abstract}
Anti-corruption campaign among successive administration has been attempting to curb the hydra-headed monster and clog in the wheel of the development progress of developing countries at large and Nigeria in particular. Essentially, the poverty and menace of poor development programmes' delivery, which Nigeria witnessed in the pre-1999 era made the Obasanjo Administration to fight the war headlong. The methodology adopted is qualitative with the usage of secondary data and observation as conscious citizens of the country who witnessed the activities of the administration against corrupt practices. This essay is therefore divided into introduction; a review of anti-corruption war; the success of institutional approach; salient lessons; conclusion and recommendations that centre on the promotion of entrepreneurship, traditional value system, honesty, sacrifice, selflessness, and discipline.
\end{abstract}

Keywords: Anti-Corruption War, the Salient Lessons, Institutional Approach, the EFCC and ICPC 


\section{Introduction}

...the administration of President Olusegun Obasanjo demonstrated a strong political will to fight economic and financial crimes by instituting several reforms to revitalise the economy and re-position the country on the path of sustainable development. He empowered the existing anti-corruption agencies with more stringent measures against offenders, and instituted new ones to deal with specific crimes. There was a huge cleanup recorded during his administration (Imam, 2014).

There is no gainsaying the fact that corruption has adversely affected the delivery of critical infrastructural development programmes and institutions of the government in Nigeria. According to Mungiu-Pippidi (2006), Médard (2002) cited in Persson, Rothstein, Teorell (2010), this situation has pressurized the government of various countries of the world to radically embark on anti-corruption war and reforms. This in the view of PAUL \& Ofuebe (2020:46) has led to the creation of "international institutions like Transparency International (TI), United Nations (UN), Organisation of Economic Cooperation and Development (OECD), European Bank for Reconstruction and Development (EBRD), World Bank (WB), World Trade Organisation (WTO), and the International Monetary Fund (IMF)" who are vigorously involved in the battle against corruption.

Hence, the Obasanjo administration between 1999 - 2007 took a pragmatic decision to fight corruption within this period because the pre-democratic era witnessed a situation where most of the areas of social and economic life in which government had intervened so heavily had failed to rise up to the challenges of growth and development (PAUL \& Ofuebe, 2020). As Persson, Rothstein, Teorell (2010:10) argued, "this insight goes hand in hand with the commonly held assertion that without a strong political will, anti-corruption reforms are bound to fail." It was noticeable that the failure of state enterprises has dragged down the development thrust of the country and enthroned huge infrastructural deficit, debilitating corrupt practices and pervasive poverty in the land (Mabonguje, 2013; Ihe, 2018).

Mabonguje (2013) wrote that the decision to deal with corrupt individuals more through the police route of the Economic and Financial Crimes Commission (EFCC) under Mallam Nuhu Ribadu rather than the judicial route of the Independent Corrupt Practices and other Related Offences Commission (ICPC) under the chairmanship of Honourable Justice Mustapha Akanbi and later Justice Tunde Ayoola did a lot to reduce the feeling of impunity and complacency. There were allegations and counter-allegations of selective arrest and prosecutions of corrupt individuals who are unbeloved of the presidency. Whether true or false, the determined manner of the agencies to a larger extent curtailed and tamed the monster (Okonjo-Iweala, 2014).

It is observed that since the Obasanjo administration came to an end in May 2007, the succeeding governments have backslidden from the anti-corruption war. The administrations that emerged after from 2007 - date have denounced the anti-corruption stance of the Obasanjo's government with a promise to clean the system, but reversely, they have entangled themselves with the act they promised to challenge. Therefore, this paper shall answer the following questions;

- Why was it important to fight corruption in Nigeria from 1999 - 2007?

- How successful were the approaches taken within period?

- What lessons can be learnt in the anti-corruption war? 


\section{Methodology}

The methodical basis of this essay is qualitative and reliance on secondary data - textbooks, journal articles, newspaper and the internet. The researchers also witnessed the Obasanjo's administration anti-corruption war as citizens of the country and this placed them as observers. This as described by Asika (1991) cited in Ibietan \& Ajayi (2015) strengthened the efficacy and significance of observation to studies of this nature that there are some situations where the method of gathering information is through a thorough observation. These methods help to situate the assumptions, deductions and recommendations within the institutional framework.

\section{The Anti-corruption War in Nigeria: A Review}

Literature subscribed to the fact that anti-corruption war and its agencies have suffered defeat following the poverty of implementation. Particularly, there is perceived scarcity and sincere implementing bureaucrats (Riley 1998; Kpundeh 2004; Svensson, 2005; Lawson 2009; Persson, Rothstein, Teorell, 2010). As a result, anti-corruption struggles have witnessed reputation challenges which have hindered successful actualisation of a corrupt-free Nigeria. It is a known issue that implementation of anti-corruption policies and mass protest against corrupt officials have been difficult.

As a corollary, some scholars like Themudo (2013) and Verdenicci \& Hough (2015) have opined citizen and civil society-centred anti-corruption probe. However, their opinions are theoretically and problematically-based without practice. Okonjo-Iweala (2014) observed that the major factor that led to the non-consolidation of all the reform of the Obasanjo economic team under her leadership was lack of inclusiveness. Perhaps, this has led to the increased criticism against the anti-corruption agencies and its headship by the members of the Nigerian Bar Association and the Bench, political class, civil society organisations, captains of industry, and business moguls. Specifically, condemnation follows "after the gradual leaking of evidence on individual prosecutorial misconduct, organizational and procedural deficiencies, aberrations from fair justice as well as numerous "collateral damages (i.e. indicted people who were eventually acquitted)" (Mendelski, 2019:3). According to Lawson (2009), related studies on Africa anti-corruption struggle are divided into best practices, topdown policy, system approaches, and the politics of anti-corruption reform. In the findings of Imam (2014), there is an absence of courage and doggedness among the successive administrations since the exit of Obasanjo in 2007.

As Folarin (2009:16) revealed, "from the Jaji Declaration in 1977 by Olusegun Obasanjo; the Ethical Revolution of Shagari in 1981 - 83; War Against Indiscipline by Buhari-Idiagbon in 1984; National Orientation Movement in 1986 and Mass Mobilisation for Social Justice by Babangida in 1987; to the War Against Indiscipline and Corruption by Abacha in 1996; it has been a litany of woes between military and civilian leaderships in Nigeria to stem corruption." From the foregoing, literature have empirically revealed that the anti-corruption agencies have not fared well, there is a lackadaisical policy implementation, paucity of capacity and personnel, the image and credibility challenge, and the absence of decisive political will by the executive arm of the government. 


\section{Importance of Anti-Corruption War}

The anti-corruption measures, fight against the advance fee fraudsters, and strive towards greater transparency in public and private sector transactions will help to ensure accountability, and send the message that those who make money through illegal and illegitimate means have no hiding place (Muhammed, 2019).

Corruption is a major poison and a challenge to the realisation of development programmes in Nigeria. Corruption creates perpetual poverty and impoverishment. It has denied the country of quality service delivery, thwarted the distribution of national resources, and has brought about injustice. Distinctively, "there cannot be any meaningful harmonious coexistence and security when the chunk population of a nation only perceives development without tasting it" (PAUL, 2019:111). As EFCC (2006) cited by Imam (2006:139) expressed, "it also has a corrosive effect on our collective integrity and discipline, and contaminates society's moral values by rewarding the unscrupulous and demoralising the honest, thereby destroying the foundations of innovation, creativity, freedom and competition." It damages the legitimacy and credibility of the state before her people.

Accordingly, PAUL (2019:111) maintained that "many of the developing countries of the world from the 1980s have their engine of economic growth reduced, thereby breaking the fence of economic prosperity for poverty and raising an urgent question of addressing all sectors (rural, urban and semi-urban areas)." Therefore, the importance of anti-corruption crusade cannot be overemphasised because the public sector has not been responsible and responsive to the efficient delivery of public services to Nigerians following perversed and corrupt practices. Corrupt attitude of public office holders has made the government and public institutions irresponsible, debarred the government from carrying out development programmes and created the situation of rent-seeking. Therefore, NEEDS Document (2004) cited by Muhammed (2019) said,

\footnotetext{
there is still the challenge of reforming the public sector into an efficient and responsive instrument for delivering services to the people; corruption and fraud need to be fought ruthlessly; infrastructure decay needs to be reversed and the private sector empowered to become competitive and lead the growth process; and the weak and vulnerable groups need to be lifted up.
}

Nigeria is a developing country that needs overall development and reform. Fundamentally, there is arbitrariness in the working of the government and its institutions at both the Federal, States and Local governments' levels, the operations of the private sector, social charter and cultural value and system reorientation. As Junaidu (2019) maintained, for example, the Obasanjo anti-corruption measure gave birth to the economic programme of privatisation of business-oriented public enterprises so as to redirect thousands of Board members into productive self-engagements. Junaidu argued that this measure is aimed at reforming the public sector to emphasize services that are selfless, efficient "(value-formoney)" and professionally-inclined. 


\section{The Success of Institutional Approach in Anti-Corruption War}

To check the malignancy of it, President Olusegun Obasanjo's administration instituted the Independent Corrupt Practices and Other Related Offences Commission (ICPC) and Economic and Financial Crimes Commission (EFCC) established by the AntiCorruption Acts of 2000 and 2002 respectively, to investigate, apprehend and prosecute individuals, groups and institutions found culpable or corrupt, and unearth frauds and recover public loots (Folarin, 2009:16).

Several attempts have been made to evaluate the efforts of the ICPC and the EFCC (the two major anti-corruption bodies established by the Obasanjo's government that tackled the menace). Their performance measurements were dependent on system and the top-down approaches. This is because Mendelski (2019:9) enunciated that an "appropriate evaluation of anti-corruption activity requires assessing the entire input-process-output chain, including the various phases of the criminal process." He quoted Recanatini (2011); Johnsøn et al. (2011), UNDP (2011) who posited that the input factors like capacity, resources, and manpower and the outputs to involve effectiveness, operational autonomy, the number of investigations, acquittal and conviction rates are required as measurement tools.

Inclusively, fundamentals of the methodology adopted by the ICPC and EFCC are the variables that include relevance, understandability, comparability, timeliness, consistency, and reliability. The presence of these measures made the Obasanjo administration's anticorruption war a success. For instance, the ICPC was mandated to operate in the area of corruption related offences that pertains to enforcement, prevention, and education and public enlightenment. The agency's achievements were:

- Filing of 39 cases in designated High Courts involving 76 very high-profile persons across the strata of Nigerian society and as at 2007, the Commission received 3000 petitions, 209 court charges in 102 cases;

- The establishment of collaborative Anti-corruption and Transparency Monitoring Units (ACTUs) in 92 government ministries, agencies, parastatals and other establishments and undertook system review exercise in not less than 43 of them; and

- Regular orientation and enlightenment campaign for the development of sound moral values and principles.

In same development, the EFCC as the second anti-corruption body of the Obasanjo's administration pursued the financial and business environment watchdog objectives of the government. Imam (2013:160 - 161) succinctly itemised the achievements of the agency between 2003 - 2007 to include, among others, the:

- Recovery of \$700 million and BPS3 million from the British government,

- Prosecution of $\$ 245$ million from a bank fraud in Brazil,

- Recovery of over N20 billion from fraudsters of the government treasury,

- Curbing of oil bunkering in the Niger Delta Region that ranges from 300,000 500,000 to the substantially reduced level of 50,000 barrels, 
- Prosecution of 20 vandals in 2005 ,

- Procurement of grants of $€ 20$ million for three years from European Union and $\$ 3$ million from the World Bank for ICT capacity building,

- Arraignment of 5 former governors and 31 indictment before the competent courts in Nigeria, and

- Increment of national revenue profile by $20 \%$ following the transparent activities of Federal Inland Revenue Service and the ports.

Basically, Folarin (2009:16) submitted that the "EFCC made unprecedented arrests of retired and serving officers, big shots in politics, governors, speakers of state legislative assemblies, bank and company chiefs, etc, and recoveries of looted funds." In totality, the anti-corruption war was fought based on the decisive political will, accountability, provision of leadership and organisational independence, and a coherent institutional structure and legal framework of the anti-corruption agencies (the ICPC and the EFCC).

\section{Salient Lessons and Governance Implications}

There are factors that made the anti-corruption war in Nigeria within the period under study relatively successful which other settings can adopt and adapt. These factors are not farfetched.

i. The anti-corruption battle de-emphasises fraud and rent-seeking and uplifted reward for hard work. Thus, people were empowered to demand for accountability from government and elected representatives. This was made possible through the Freedom of Information Act that empowered the press.

ii. The qualities of hard work, integrity, honesty, selfless service, morality, and patriotism were cherished.

iii. The anti-corruption war was not devoid of strengthening of the public enlightenment organs of the state.

iv. The struggle consolidated the ethics of religious and socio-cultural/traditional groups, encouragement of Non-governmental Organisations, Community-Based Organisations, and the private sector organisations for the provision of leadership for value system revalidation. This is because "several researches have confirmed the buoyancy, authority and importance of African traditional structures in the politicocultural and socio-economic operations of Africans" (PAUL, Alih \& Audu, 2017:1).

From the foregoing important points, Ihe (2018) and Hoxhaj (2019) asserted that a situation of feeble-minded civil society and non-performance of the mechanics of institutions in dealing with corrupt practices is dangerous for anti-corruption war. Nonetheless, enlargement of the reward system of the Nigerian National and Institutional Merit Award initiatives is thoughtful and motivational. 


\section{Conclusion and Recommendations}

The need to reposition the value and ethical system over rent-seeking, looking up to amassing wealth from the taxpayers' money, the quick-rich syndrome with expectation of something from nothing are long overdue. Entrepreneurship, traditional value system, honesty, sacrifice and selflessness, and discipline should be promoted. 


\section{References}

Folarin, S. (2009). The anti-corruption war in Nigeria: A critical appraisal of the role of the ICPC and EFCC. Nigerian Journal of Economic and Financial Crimes, 1(2), 14 - 36.

Hoxhaj, A. (2019). Civil society needs support to fight corruption and organised crime in the Western Balkans. LSE: European Politics and Policy, October, 30.

Ibietan, J. \& Ajayi, O. O. (2015). The Governing Elite and Democratic Consolidation in Nigeria: An Appraisal of the Fourth Republic. Journal of Human and Social Science Research, 6 (1), 14 - 21. Accessed from http:/leprints.covenantuniversity.edu.ng/ on $12 / 10 / 2020$

Ihe, N. J. (2018). Historical and Criminological Analysis of Corruption: A Case Study of Nigeria. A doctoral dissertation, submitted to the Texas Southern University.

Imam, B. (2014). Anti-corruption crusade. In O. Akinkugbe \& A. Joda (ed), Olusegun Obasanjo: The presidential legacy, 1999 - 2007, 138 - 165. Ibadan: BOOKCRAFT Ltd.

Junaidu, K. O. (2019). Public sector reform and service delivery in Nigeria. Public Service Delivery Review, 4(2), 45 - 55.

Kpundeh, S. J. (2004). Building state capacity in Africa. Washington: The World Bank.

Lawson, L. (2009). The Politics of Anti-Corruption Reform in Africa. Journal of Modern African Studies, 47 (1), 73-100.

Mabogunje, A. (2013). Olusegun Obasanjo: The man. In O. Akinkugbe \& A. Joda (ed), Olusegun Obasanjo: The presidential legacy, 1999 - 2007, 2 - 27. Ibadan: BOOKCRAFT Ltd.

Mendelski, M. (2019). 15 Years of Anti-Corruption in Romania: Augmentation, Aberration and Acceleration

Muhammed, S. D. (2019). Nigeria public sector in the storm of corruption. A paper presented at the 3 Day Summit of National Association of Polytechnic Public Administration Students, Abeokuta, July 16-18.

Okonjo-Iweala, N. (2014). Reforming the unreformable: Lessons from Nigeria. Mit Press.

PAUL, S. O. \& Ofuebe, C. (2020). Unabated Corruption in the government of Nigeria despite the Economic and Financial Crimes Commission: Who bells the cat? Society \& Sustainability, 2(2), 45 - 58 . Doi: https://doi.org/10.38157/society_sustainability.v2i2.129

PAUL, S. O., Alih, M. A., \& Audu, E. (2017). Public Administration and traditional administrative system in Africa: An Interdependency Discourse. Management, 1(1), 1 - 15. DOI: 10.31058/j.mana.2017.11001 
PAUL, S. O. (2019). National Urban Development Policy and the Unanswered Development Question of Slum in Nigeria. International Journal of Public Policy and Administration Research, 6(2), 102-115. Doi: DOI: 10.18488/journal.74.2019.62.102.115

Persson, A. Rothstein, B. Teorell, J. (2010). The failure of anti-corruption policies: A theoretical mischaracterization of the problem. QoG Working Paper Series 2010:19 Department of Political Science University of Gothenburg, June.

Riley, S. P. (2000). Western Policies and African Realities: The New Anti-Corruption Agenda. In K. R. Hope Sr. \& B. C. Chikulo (ed), Corruption and development in Africa: Lessons from Country Case Studies, 137 - 160. Basingstoke: MacMillan Press Ltd.

Svensson, J. (2005). Eight questions about corruption. Journal of Economic Perspectives, 19 (3), $19-42$.

Themudo, N. S. (2013). Reassessing the impact of civil society: Non-profit sector, press freedom, and corruption. Governance, 26(1), 63-89.

Verdenicci, S. \& Hough, D. (2015). People power and anti-corruption; demystifying citizencentred approaches. Crime Law Social Change, 64(1), 23-35. https://doi.org/10.1007/s10611-015-9585-3 